University of Nebraska - Lincoln

DigitalCommons@University of Nebraska - Lincoln

Mammalogy Papers: University of Nebraska

State Museum

Museum, University of Nebraska State

$11-1-1971$

\title{
Second Specimen of Oryzomys dimidiatus
}

Hugh H. Genoways

Texas Tech University, h.h.genoways@gmail.com

J. Knox Jones Jr.

Texas Tech University

Follow this and additional works at: https://digitalcommons.unl.edu/museummammalogy

Part of the Zoology Commons

Genoways, Hugh H. and Jones, J. Knox Jr., "Second Specimen of Oryzomys dimidiatus" (1971).

Mammalogy Papers: University of Nebraska State Museum. 46.

https://digitalcommons.unl.edu/museummammalogy/46

This Article is brought to you for free and open access by the Museum, University of Nebraska State at DigitalCommons@University of Nebraska - Lincoln. It has been accepted for inclusion in Mammalogy Papers: University of Nebraska State Museum by an authorized administrator of DigitalCommons@University of Nebraska Lincoln. 


\section{SECOND SPECIMEN OF ORYZOMYS DIMIDIATUS}

The species Oryzomys dimidiatus was originally named and described by Thomas (Ann. Mag. Nat. Hist., ser. 7, 15:584-591, 1905) as a member of the genus Nectomys on the basis of a single specimen from the Río Escondido, 7 miles below Rama, Nicaragua (approximately $1 \mathrm{~km}$. S and 81/2 km. E Rama, $20 \mathrm{~m}$, Zelaya), obtained by W. G. Palmer on 5 November 1904. Although there has been speculation on the relationships of this taxon (currently regarded as the only member of the subgenus Micronectomys, genus Oryzomys-see Hershkovitz, J. Mamm., 51:789-794, 1970, for review), the holotype has remained the only known specimen.

A second individual (University of Kansas Museum of Natural History no. 106607) assignable to this species was taken on 26 July 1966 by R. W. Turner at El Recreo, $25 \mathrm{~m}$, Zelaya, Nicaragua, approximately 15 kilometers to the west of the type locality. This rat, a young adult male, was trapped in a stand of cane, 8 to 10 feet tall, along the south bank of the Río Mico. The cane was nearly impenetrable excepting for two paths through it to the river, and it was along these paths that traps were set, baited with rolled oats. In addition to $O$. dimidiatus, other small mammals taken at this place included Oryzomys caliginosus, $O$. fulvescens, O. palustris, Sigmodon hispidus, and one Sylvilagus brasiliensis that was shot along the edge of the cane.

Measurements (in millimeters) of our specimen followed by (in parentheses, when available) those of the holotype given by Hershkovitz (op. cit.) are: head and body, 118 (125); length of tail, 110 (115); length of hind foot, 28 (27, dry); length of ear, 15 (13); greatest length of skull, 29.0 (29.8); condylobasal length, 26.7 (27.2); zygomatic breadth, 15.0 (16.8); interorbital breadth, 4.5 (5.2); breadth of braincase, 11.9 (12.3); mastoid breadth, 11.5; interparietal, $2.5 \times 6.9(2.9 \times 7.4)$; length of nasals, $10.7(11.7)$; breadth of zygomatic plate, 2.7 (3.1); rostral width, 5.6 (6.1); rostral length, 10.1; length of incisive foramina, 5.9 (6.5); length of diastema, 7.4 (7.5); length of palatal bridge, 5.5; length of maxillary toothrow, 4.4 (4.7); crown length of M1, 2.0 (2.2); breadth across upper molars, 5.4 (6.2); length of mandibular toothrow, 4.5; weight (grams), 46.0. The testes were 11 millimeters long.

Of the species of Oryzomys occurring in eastern Nicaragua, $O$. dimidiatus closely resembles O. palustris, but differs from that species most conspicuously in smaller external and cranial size, less robust dentition, darker (more black evident) dorsal coloration, grayish as opposed to buffy venter, and proportionally shorter tail (clearly shorter than the length of head and 
body in dimidiatus, whereas in palustris the tail and head and body are approximately the same length).

Field work in Nicaragua was supported by a contract (DA-49-193-MD-2215) from the U. S. Army Medical Research and Development Command. We are grateful to Philip Hershkovitz of the Field Museum of Natural History for confirming the identification of the rice rat here reported.-Hugh H. Genoways And J. Knox Jones, JR., The Museum, Texas Tech University, Lubbock, 79409. Accepted 20 June 1971. 